\title{
AN INVESTIGATION OF SYRIAN ASYLUM SEEKERS' ATTITUDES TOWARD THEIR SITUATION IN TURKEY
}

Latife KABAKLI ÇİMEN ${ }^{1}$

Seher ERSOY QUADİR ${ }^{2}$

\section{Abstract}

Syrians began to take refuge in Turkey on 29 April 2011 due to the civil war started in their country and their number in Turkey reached over 3.5 million by the year 2019 (Refugees Association, July 29, 2019). This study was conducted to examine the attitude of Turkey regarding Syrian asylum seekers. The sample group consisted of 233 Syrian people who were residing in two cities in different conditions in Turkey in 2017. The sample was selected among the Syrian asylum seekers by cluster sampling method. Research data were obtained using «Syrian Asylum Seekers' Attitude towards Turkey Scale» developed by the authors. The relationship between this scale and demographic characteristics of the sample group was analyzed by calculating Pearson Correlation Coefficient. In findings sample group has a positive opinion about Turkey in general. But who are living in asylum seeker camps in Osmaniye have more satisfaction as an asylum seekers than those who are residents in Istanbul with their own facilities and limited state aid. Overall asylum seekers don't participate that the problems caused by the Syrians in Turkey. Especially, those who living in Istanbul, who have a high level of education and who are responsible from less people were more opposed this idea.

Key words: Syrian asylum seekers' satisfaction, reasons of Syrians' asylum to Turkey, Syrians' attitudes about Turkey, the problems caused by the Syrians in Turkey, difficulties of being anasylum seekers.

\footnotetext{
${ }^{1}$ Doç. Dr., İstanbul Sabahattin Zaim Üniversitesi, Temel Eğitim Bölümü, E-Posta:latife.cimen@izu. edu.tr ORCID: 0000-0002-4973-3630

${ }^{2}$ Doç. Dr., Necmettin Erbakan Üniversitesi, Sosyal Hizmet Bölümü, E-Posta: seherers@gmail.com ORCID: 0000-0001-7492-5100

KABAKLI CIIMEN, L., ERSOY QUADIR, S. (2021) An Investigation Of Syrian Asylum Seekers' Attitudes Toward Their Situation in Turkey. Sosyal Politika Çalışmaları Dergisi, 21(50), 10-43. DOI: 10.21560/spcd.vi.613739
} 


\section{SURIYELİ SIĞINMACILARIN TÜRKIYE'DEKİ DURUMLARINA YÖNELIK TUTUMLARININ ARAŞTIRILMASI}

\section{O̊z}

Suriyeliler ülkelerinde başlayan iç savaş nedeniyle 29 Nisan 2011'de Türkiye'ye sığınmaya başladılar ve Türkiye'deki sayıları 2019 yılı itibariyle yaklaşık 3,5 milyona ulaşmıştır (Mülteciler Derneği, 29 Temmuz 2019). Bu araştırma, Suriyeli sığınmacıların Türkiye ile ilgili tutumlarını incelemek amacıyla gerçekleştirilmiştir. Araştırmanın örneklemini 2017 yılında İstanbul il merkezinde ikamet eden ve Osmaniye’de sığınmacı kamplarında yaşayan Suriyeli sığınmacılar arasından küme örneklem yöntemi ile belirlenen toplam 233 kişi oluşturmuştur. Araştırmanın verileri Kabaklı Çimen ve Ersoy Quadir tarafından geliştirilen "Suriyeli Sığınmacıların Türkiye ile İlgili Tutum Ölçeği” kullanılarak elde edilmiştir. Daha sonra da bu ölçeğin örneklem grubunun demografik özellikleriyle ilişkisi Pearson Korelasyon Katsayısı hesaplanarak irdelenmiştir. Araştırma sonuçlarına göre örneklem grubu genel olarak Türkiye hakkında olumlu fikre sahiptir ve bu memnuniyet Osmaniye'de kamplarda kalanlarda daha fazladır. İstanbul'da kendi imkânlarıyla ikamet edenler sığınmacı olarak yaşamaktan daha çok rahatsızlık hissetmektedir. Genel olarak sığınmacılar Türkiye'deki problemlerin Suriyelilerden kaynaklandığına katılmamakta; özellikle İstanbul'da ikamet edenlerin, eğitim düzeyi yüksek olanların ve bakmakla sorumlu olduğu kişi sayısı az olanların kesinlikle katılmama oranı daha fazladir.

Anahtar kelimeler: Suriyeli sığınmacıların memnuniyeti, Suriyelilerin Türkiye’ye sığınma nedenleri, Suriyelilerin Türkiye hakkındaki tutumları, Türkiye'de Suriyelilerden kaynaklanan problemler, sığınmacı olmanın zorlukları. 


\section{INTRODUCTION}

An asylum seeker goes to another region and unknown future to rescue his life and/or his family's life. During this expedition, some economic and even cultural gains are experienced, but at the same time, they have to separate from their own community (Teber, 1993: 9-16). In this process, social environment interactions, daily habits and behaviors can be lost. This situation can lead to a number of serious mental problems and trauma. Because migration brings many stress factors (such as adaptation to a different socio-cultural environment, climate, place and house change, change of workplace, change of work style, temporary or permanent separation from family members, change in life style, change of school, change in economic situation) and causes many emotional and physical reactions. These difficulties before and after forced migration may cause many problems in individuals and families such as post traumatic stress disorder, attachment and adjustment problems, anxiety, mood disorder and substance abuse. In summary, forced migration is a spiritual experience with many losses. Those psychological problems most often affect children and women. Especially for children and adolescents who are going through a risky development phase, stable environmental factors are very important, hence instability is very dangerous (Ilgar and Çoşkun Ilgar, 2015, p.160-169; Oral and Tuncay, 2012, p.103). Indeed, Özer and Şirin (2013) reported based on field research on Syrian asylum seekers living in camps in Turkey, $4.4 \%$ of adolescents informed their need to see a doctor because of psychological problems and $2.6 \%$ of children were diagnosed with a psychiatric diagnosis by a doctor. In the same study, it was found that the psychological problems experienced by the Syrian asylum seekers mostly affected children and women; because it is emphasized that more than $75 \%$ of Syrians are children and women. In the findings of other studies, it was determined that most of the Syrian women exposed to migration face human rights violations such as sexual violence, economic inequality (Barın, 2015), sexual harassment, polygamy and early marriage (Acar et al., 2015; Aktaş, 2016). 
Especially for children and adolescents who are going through a risky developmental stage, it is very important that the environmental factor is stable and its deterioration has the following negative consequences: In the study of Önen, et al. (2014), 19.3\% of the Syrians living in Akçakale Asylum Seeker Camp in Şanlıurfa had severe anxiety symptoms; Symptoms of severe depression were found in 8.9\%. In the study of Özer and Şirin (2013), 49\% of the Syrian children living in the camps experienced high levels of depression, $36 \%$ had clinical depression scores, and 12.7-25.8\% had psychosomatic problems (headache, abdominal pain, pain in the arms etc.). All these findings show that asylum seekers have problems in terms of mental health.

The school environment for Syrian children is another source of stress. When the literature on the impact of migration on the child is examined, significant findings have been obtained: In a study conducted by PolatUluocak (2009), teachers reported about twice as many neurotic problems in children who migrated compared to their peers who did not. Moreover, in schools in the regions with migration, the classes become crowded and this makes the students more passive as the teacher cannot deal with the concern of complete the curriculum adequately with each student (Bayraktar, 1999; Karakuş, 2006). In this case, immigrant children find it difficult to learn the language of the region they live in, fail to express themselves in class and the level of success in class decreases. They are excluded from their classmates and may exhibit disciplinary actions by establishing small groups with other immigrant students in order to show themselves (Angay, 2012; Bayraktar, 1999; Bingöl, 2006; Karakuş, 2006). Asylum seekers, who do not know Turkish or speak little Turkish, especially in high school age, are trying to contribute financially to their families by not going to school due to economic concerns, thus the problem of child labor continues in the country (Korkmaz, 2016: 98). The fact that children go away from school life and start working on the streets 
(selling handkerchiefs, shoe dyeing, etc.) due to the inadequate support of children's education life causes them to become vulnerable to external dangers (Akgül and Polat Uluocak, 2010: p.10). In fact, according to the findings of Emmen et al. (2012), migrant parents seem less sensitive to supporting the development of their children, not only because of cultural differences, but also because migrant families generally have more disadvantaged socioeconomic (education and income) conditions than the dominant group (Retrieved from Durgel and Yağmurlu, 2014: p.8).

Actually, $40 \%$ of Syrian immigrants are unemployed and this is the biggest problem of this disadvantaged group (Sosyo Politik Saha Araştırmaları Merkezi, 2019). Therefore the majority of the Syrian asylum seekers in our country live in difficult conditions outside the camps. Those who live in large cities outside the camps are often unable to fully meet their family's nutritional, shelter, hygiene and other basic needs. While Germany has accepted about $70.0 \%$ of Syrians are university graduates, only $7.0 \%$ of Syrians in Turkey are university graduates (Koçanc1, February 19, 2018). For this reason, as determined by Özkarslı (2011), women and men in this mass with low education generally work in unskilled daily jobs (construction worker, cleaning worker, daily baby / child caregiver, agricultural laborer, porter, industrial worker, textile worker, shepherd, restaurant employee, chauffeur etc.). In the same study, it was found that 43 percent of the Syrians earn monthly, 35 percent daily, 15 percent weekly, and 7 percent of them earn income for daily meal (Özkarsl1, 2011). As also been found in some other studies, Syrians living in Turkey usually in unskilled jobs (deprived of social security and state protection) and work in severe conditions (Göde et al., 2014; MAZLUMDER, 2014: p.25-29).

The civil war in Syria has been going on since 2011. Therefore, according to December 2019 data, the positions of a significant portion of the Syrians with 
registered numbers of more than 3.5 million in Turkey (Mülteciler Derneği, 30 Aralık 2019) have become permanent. According to TUIK $(2017,2018)$ marriage and divorce statistics, Syrian brides ranked first among foreign brides with $19.4 \%$ in 2017 and $15.7 \%$ in 2018. In this way, Syrians adaptation has become increasingly important with social, political and economic dimensions. Syrians' attitude about their situation in Turkey need to be revised for facilitate their integration to Turkey (asylum policy, asylum seekers' life circumstances and attitude of the Turkish people). Therefore, this research aimed to investigate the attitudes of Syrians who living in camps and living independently in the city about their situation in Turkey.

Depending on the purpose of the research, the following hypothesis has been tested:

Syrian asylum seekers;

1. Who are residing in camps in Osmaniye,

2. Who are residents for a long time,

3. Who are older,

4. Who are less educated,

5. Who are married,

6. Those with higher income levels,

7. Who has reported a good housing conditions,

8. Who are responsible to take care of too many people, have a more positive attitude about Turkey.

\section{DATA AND METHODS}

\section{Participants}

The sample group of the study consisted of 97 independent Syrian asylum seekers living in Istanbul and 136 Syrian asylum seekers living in asylum seeker 
camps in Osmaniye in 2017. The Syrians who came to learn Turkish within the scope of TÖMER (Turkish Learning Research and Application Center) language education of a private university in Istanbul and Syrians living in asylum seeker camps in Osmaniye were determined by cluster sampling method. The demographic characteristics of the sample group were examined in Table 1.

As shown in Table 1, 54.1\% of the Syrians participating in the study were male and $45.9 \%$ were female. In addition, $67.8 \%$ of the sample group were under the age of 30 and $32.2 \%$ were over 30 years of age. Of the respondents, $32.2 \%$ were high school graduates, $27.9 \%$ were secondary school graduates, $20.6 \%$ were primary school graduates and less educated, $19.3 \%$ were university or higher graduates. More than half of the respondents $(58.8 \%)$ were single and $41.2 \%$ were married. In the study $36.0 \%$ of the sample were not working in a paid job, $35.2 \%$ were students, $3.0 \%$ were retired; only $23.2 \%$ group was employed while the group with $2.6 \%$ was the employer. In this case, $44.7 \%$ of the sample group naturally had less income than the minimum wage, $13.3 \%$ had a minimum wage level income, $28.3 \%$ had an average income level, and $13.7 \%$ had income above the average. Nearly half of the study group (46.3\%) had a moderate level of housing condition, $25.8 \%$ had a good level, $17.2 \%$ had a poor level and $10.7 \%$ had a very good level. In the sample group, $34.8 \%$ of the participants were responsible to take care of $4-8$ people, $33.0 \%$ were responsible to take care of $1-3$ people and $32.2 \%$ were not responsible to take care of anybody (probably because they were students). 
Table 1. Demographic Characteristics of Syrian Asylum Seekers $(n=233)$

\begin{tabular}{|c|c|c|c|c|c|}
\hline Gender & $\mathrm{n}$ & $\%$ & $\begin{array}{l}\text { How many years lives in } \\
\text { Turkey }\end{array}$ & $\mathrm{n}$ & $\%$ \\
\hline Woman & 107 & 45.9 & 3 years and less & 97 & 41.6 \\
\hline Man & 126 & 54.1 & 4 and more years & 136 & 58.4 \\
\hline Age & & & Coming with relatives & & \\
\hline 19 years and under & 72 & 30.9 & Yes & 127 & 54.5 \\
\hline Between 20-29 years & 86 & 36.9 & No & 106 & 45.5 \\
\hline 30 years and older & 75 & 32.2 & $\begin{array}{l}\text { Relative's effect to compliance } \\
(\mathrm{n}=127)\end{array}$ & & \\
\hline Home city & & & Effective & 81 & 63.8 \\
\hline İstanbul & 97 & 41.6 & Partially effective & 33 & 26.0 \\
\hline Osmaniye & 136 & 58.4 & Not effective & 13 & 10.2 \\
\hline Education level & & & $\begin{array}{l}\text { Adaptation problem with } \\
\text { public }\end{array}$ & & \\
\hline Not literate & 7 & 3.0 & Yes I've had a problem & 19 & 8.2 \\
\hline Literate & 20 & 8.6 & No I haven't had a problem & 214 & 91.8 \\
\hline Primary school graduates & 21 & 9.0 & $\begin{array}{l}\text { Reasons of adaptation } \\
\text { problem with public }\end{array}$ & & \\
\hline Secondary school graduates & 65 & 27.9 & Language problem & 7 & 3.0 \\
\hline High school or equivalent graduates & 75 & 32.2 & Cultural differences & 5 & 2.2 \\
\hline University graduates or higher & 37 & 15.9 & Negative words about refuges & 2 & 0.9 \\
\hline Master's Degree/ Doctorate & 8 & 3.4 & $\begin{array}{l}\text { The problem of subsistence } \\
\text { and housing }\end{array}$ & 2 & 0.9 \\
\hline Marital status & & & Difficulty at university & 1 & 0.4 \\
\hline Single & 116 & 49.8 & Being abused in the van & 1 & 0.4 \\
\hline Married & 96 & 41.2 & Problem with the host & 1 & 0.4 \\
\hline Widow & 7 & 3.0 & Reasons to leave Syria * & & \\
\hline Divorced & 6 & 2.6 & Life-threatening & 177 & 76.0 \\
\hline
\end{tabular}


Living separately

Income rate

Has income above average

Average income level

Income at minimum wage level

Less income than minimum

wage

Paid work

Working

Not Working

Student

Retired

Employer

Housing conditions

Very good

Good

Moderate

$\mathrm{Bad}$

Number of people being cared for

Nobody

1-3 persons

4-8 persons
$8 \quad 3.4 \quad$ Economic reasons

$24 \quad 10.3$

Holding the family

$42 \quad 18.0$ together

$32 \quad 13.7$ Avoiding work

$12 \quad 5.6$

$66 \quad 28.3$ Transition to European Union Countries

$31 \quad 13.3 \quad$ To go to college

$\begin{array}{ll}7 & 3.0\end{array}$

10444.7 Type of support he/she received from Turkey* Not getting support

$28 \quad 12.0$

$54 \quad 23.2$ Housing

$25 \quad 10.7$

$84 \quad 36.0$ Food

$\begin{array}{ll}70 & 30.0\end{array}$

$82 \quad 35.2$ Pocket money

$\begin{array}{ll}40 & 17.2\end{array}$

$7 \quad 3.0$ Health care costs

$\begin{array}{ll}78 & 33.5\end{array}$

$6 \quad 2.6$ Education

$92 \quad 39.5$

Getting information

$17 \quad 7.3$

$25 \quad 10.7$ Official transactions

$14 \quad 6.0$

$60 \quad 25.8$ Coal (for warming)

$\begin{array}{ll}4 & 1.7\end{array}$

$108 \quad 46.3$ Job

$\begin{array}{ll}4 & 1.7\end{array}$

$40 \quad 17.2$ Source of support *

From $\quad 91 \quad 39.1$

government

$75 \quad 32.2$ From association

$\begin{array}{ll}87 & 37.3\end{array}$

$77 \quad 33.0$ From foundation

$35 \quad 15.0$

8134.8 From a person

\footnotetext{
* Multiple options are marked.
} 
More than half of the sample (58.4\%) lived in our country for 4 and more years, $41.6 \%$ in our country for 3 or less years. More than half of the participants $(54.5 \%)$ came to our country with their relatives and nearly half (45.5\%) were independent of their relatives. Among the respondents, $63.8 \%$ of those who came with their relatives stated that their relatives were influential to compliance the country, $26.0 \%$ were partially effective and $10.2 \%$ were not effective. Almost all of the sample group (91.8\%) reported that they did not have any adaptation problems in our country and $8.2 \%$ had problems. The majority of the people who lived problem; experienced difficulty in being in different languages (3.0\%) and in different cultures (2.2\%). This was followed by "negative words about asylum seekers" (0.9\%), "problems of livelihood and housing" (0.9\%), "difficulty in university" (0.4\%), "sexual abuse in minibus" (0.4\%), "problems with landlord" (0.4\%) (see Table 1$)$.

The main reason for leaving their country of the research group was "lifethreatening" (76.0\%). This was followed by keeping the family together (18.0\%), economic reasons (10.3\%), avoiding work (5.6\%), transition to European Union countries (3.9\%), and going to university (3.0\%). In Turkey, on October 13, 2014, No. 2014/6883 “Temporary Protection Regulations" in accordance, participants benefit from feeding and housing services (m.38), health care (m.27), educational services (m.28), access to labor market services ( m.29), benefits from social assistance and services (m.30) and interpreting services (m.31) (Uzun, 2015: 113). When the support received by the respondents to the survey is examined cumulatively, they receive education (39.5\%), health (33.5\%), food (30.0\%), allowance (17.2\%), housing (10.7\%), obtaining information (7.3\%), official transactions (6.0\%), coal (1.7\%) and work (1.7\%). Some of the participants $(12.0 \%)$ reported that they did not receive any help. This may be due to the fact that they do not apply to official institutions for fear of deportation. The participants reported that they received help 39.1\% 
from the state, $37.3 \%$ from the association, $15.0 \%$ from the foundation and 8.2\% from the individual (see Table 1).

\section{Data Collection}

\subsection{Personal information form}

Asylum seekers were asked about their demographic characteristics (gender, age, education, marital status, income level, labor force participation, housing conditions, number of people being cared for) as well as how many years they have been in our country, for what reasons he/she left homeland, coming with family members and / or close relatives, have they any experienced problem with the citizens of the Republic of Turkey, what kind of support he/ she received from Turkey to sustain life and from which channel they received the support.

\subsection{Syrian asylum seekers' attitude about their situation in Turkey scale}

The scale was developed to determine Syrian asylum seekers' attitudes about their situation and asylum policy in Turkey by Kabaklı Çimen and Ersoy Quadir. The attitude scale was of a five-degree Likert type consisting of the following five self-assessing scores: Strongly agree $=5$ points, Agree $=4$ points, Undecided $=3$ points, Disagree $=2$ points, and Strongly disagree $=1$ point. Of the 33 propositions in the scale, $7(8,9,10,11,12,13,14)$ were the reverse and the score was reversed (Strongly agree $=1$ point....Strongly disagree $=5$ ).

The study was reviewed and approved by the İstanbul Sabahattin Zaim University Ethics Review Committee. 


\subsection{Validity and reliability of "Syrian refuges' attitude about their situation}

\section{in Turkey scale"}

To test the compatibility of the data for the factor analysis, Kaiser-MeyerOlkin (KMO) sampling efficiency test and the Bartlett test were administered. With the KMO value over 0.50 and the Bartlett test value less than 0.05 , these data were found appropriate for the factor analysis $(\mathrm{KMO}=0.601, \chi 2 \mathrm{Bartlett}$ test $(528)=1.4030003, \mathrm{p}=0.0001)($ see Table 2$)$.

The attitude statements whose efficiency were below 0.50 and those which were left alone under a factor and which had similar factor loads or whose factor loads were below 0.30 were not found. After the factor analysis, 12 factors were found with eigenvalues 1 or more. When reliability test of the 12 factors were done; in the reliability analysis of each factor, 9 items $(1,2,3,6,7,8,13,26,28)$ that were determined by Cronbach's Alpha value and which distort the internal consistency of the factor were excluded from the analysis. In the repeated factor analysis with the remaining propositions, 3 factors with eigenvalues 1 and above were obtained.

At the end of this factor analysis, altogether there were 3 factor categories. Factor dimensions were named "Have a positive opinion about Turkey," "Uncomfortable living as an asylum seeker," and "Agree that some of the problems caused by the Syrians in Turkey" respectively. As a result of the factor analysis, the number of statements in the scale decreased from 33 to 24 and the total explained variance was $32.145 \%$ (see Table 2). 
Table 2. Explanatory Factor Analysis Results of the "Syrian Asylum Seekers' Attitude About Their Situation in Turkey Scale"

\begin{tabular}{|c|c|c|c|c|}
\hline $\begin{array}{l}\text { Name of the } \\
\text { factor }\end{array}$ & Attitude expression & $\begin{array}{l}\text { Factor } \\
\text { loads }\end{array}$ & $\begin{array}{c}\text { Explanatory } \\
\text { of the factor } \\
\text { (\%) }\end{array}$ & Reliability \\
\hline $\begin{array}{c}\text { Have a positive } \\
\text { opinion about } \\
\text { Turkey }\end{array}$ & $\begin{array}{l}\text { 4. I think the citizens of the Republic of Turkey are good host. } \\
\text { 5. I'm pleased with the help I got from the official institutions of the } \\
\text { Republic of Turkey until now. } \\
\text { 15. I feel a cultural similarity with the citizens of the Republic of } \\
\text { Turkey. } \\
\text { 20. I think the citizens of the Republic of Turkey have good approach } \\
\text { to asylum seekers. } \\
\text { 21. I also recommend immigration to my citizens stayed in Syria. } \\
\text { 23. If the war ends in Syria; I want to stay in a temporary-safe area until } \\
\text { Syria is reconstructed. } \\
\text { 24. If the war ends in Syria; I want to stay in Turkey and continue my } \\
\text { life here. } \\
\text { 27. The citizens of the Republic of Turkey understand us, they are } \\
\text { usually willing to help. } \\
\text { 29. Syrian asylum seekers should be given work permit in Turkey. } \\
\text { 30. The Republic of Turkey applies a good management on asylum } \\
\text { seekers. } \\
\text { 31. Syrian asylum seekers in Turkey should be given the right to } \\
\text { citizenship. } \\
\text { 32. I do not find it right for some Syrian asylum seekers to beg on the } \\
\text { streets. } \\
33 \text {. In some cities, I find justify being treated harshly to some of the } \\
\text { Syrian asylum seekers who commit crimes. }\end{array}$ & $\begin{array}{l}0.506 \\
0.551 \\
0.422 \\
0.300 \\
0.464 \\
0.370 \\
0.485 \\
0.554 \\
0.399 \\
0.430 \\
0.364 \\
0.456\end{array}$ & 13.806 & 0.694 \\
\hline $\begin{array}{l}\text { Uncomfortable } \\
\text { living as an } \\
\text { asylum seeker }\end{array}$ & $\begin{array}{l}\text { 16. I think I faced discrimination in Turkey. } \\
\text { 17. I'm being treated like foreigners in Turkey. } \\
\text { 18. I feel like foreigners in Turkey. } \\
\text { 19. I have difficulty communicating with the Turks due to the language } \\
\text { factor. } \\
\text { 22. I need psychological support because of my situation. } \\
\text { 25. If the war ends in Syria, I want to go back to my homeland. }\end{array}$ & $\begin{array}{l}0.649 \\
0.633 \\
0.661 \\
0.414 \\
0.321 \\
0.472\end{array}$ & 10.003 & 0.610 \\
\hline \multirow[t]{3}{*}{$\begin{array}{l}\text { Agree that some } \\
\text { of the problems } \\
\text { caused by the } \\
\text { Syrians in } \\
\text { Turkey }\end{array}$} & $\begin{array}{l}\text { 9. I think, Syrian asylum seekers will increase the crime rate in Turkey. } \\
\text { (-) } \\
\text { 10. I think Syrian asylum seekers are a potential threat to Turkey's } \\
\text { demographic structure.(-) } \\
\text { 11. I think Syrian asylum seekers are a potential threat to Turkey's } \\
\text { economic structure. (-) } \\
\text { 12. I think Syrian asylum seekers are a potential threat to Turkey's } \\
\text { political structure. (-) } \\
\text { 14. I think Syrian asylum seekers are contributing to the terrorist } \\
\text { incidents in Turkey. (-) }\end{array}$ & $\begin{array}{l}0.628 \\
0.526 \\
0.542 \\
0.667 \\
0.501\end{array}$ & 8.336 & 0.616 \\
\hline & & Total & \multicolumn{2}{|l|}{32.145} \\
\hline & \multicolumn{2}{|c|}{$\begin{array}{r}\text { Reliability of Kaiser-Meyer-Olkin } \\
\text { Bartlett Sphericity Test Chi square } \\
\text { Sd } \\
\text { p value }\end{array}$} & $\begin{array}{l}0.601 \\
1.403 \mathrm{E} 3 \\
528 \\
0.0001\end{array}$ & \\
\hline
\end{tabular}


Statistical analysis was performed to test the overall reliability of the scale. The reliability coefficient for the scale was found to be Alpha $=0.601$ for 24 items and this value (as the number of statements is low) indicates that the scale is sufficiently reliable. Cronbach's Alpha was used to evaluate content coherency (reliability) of the 3 factor dimensions obtained after factor analysis (these values were $0.694 ; 0.610 ; 0.616$, respectively) (see Table 2 ).

"Reliability coefficients range between 0 and 1 . The closer the coefficient is to 1 , the more reliable the measure is, with less random errors. While interpretations of reliability coefficients may vary from one researcher to another, as general guideline, a reliability coefficient greater than 0.80 is considered excellent, 0.70 to 0.80 is considered very good, 0.60 to 0.69 is considered acceptable, and a reliability coefficient less than 0.60 is considered weak due to the high proportion of random errors." (Abu-Bader, 2011: 12). That means in social science, the acceptable $\alpha$ value is 0.60 , which is also practiced by other researchers (Ary, Jacobs, Razavieh, and Sorensen, 2009: 249; Ghazali, 2008; Hair, Black, Babin, and Anderson, 2010).

\section{Analysis}

In the study, the sample group's 'Syrian Asylum Seekers' Attitude about Their Situation in Turkey Scale" scores were interpreted as tables according to their average. In addition, Pearson Correlation Coefficient is used to determine whether there is a significant relationship between Syrian asylum seekers' demographic characteristics and their attitudes about their situation in Turkey. 


\section{RESULTS}

In this section we examined the sample group of Syrian asylum seekers' attitudes about their situation in Turkey. Firstly, the average scores of each factor; then, the relationship between the independent variables (demographic characteristics) and the attitudes of Syrian asylum seekers were examined.

\section{Investigation of the Attitude of the Sample Group about Their Situation} in Turkey

The sample group included in the research has a positive opinion about Turkey $(\overline{\mathrm{X}}=3.40)$; They are undecided about discomfort as an asylum seeker $(\overline{\mathrm{X}}=3.02)$ and they did not accept some of the problems that arise from the Syrians in Turkey $(\overline{\mathrm{X}}=3.44)$ (see Table 3$)$.

Table 3. Average score of attitude of the sample group about their situation in Turkey $(n=233)$

\begin{tabular}{|c|c|c|c|c|c|c|}
\hline Name of the factor & Number of items & Minimum & Maximum & $\overline{\mathbf{X}}$ & Sx & Sum \\
\hline Factor 1: Have a positive opinion about Turkey & 13 & 2.08 & 5.00 & $3.40^{*}$ & 0.57 & 789.54 \\
\hline Factor 2: Uncomfortable living as an asylum seeker & 6 & 1.00 & 5.00 & 3.02 & 0.72 & 703.17 \\
\hline $\begin{array}{l}\text { Factor 3: Agree that some of the problems caused by } \\
\text { the Syrians in Turkey (-) }\end{array}$ & by 5 & 1.60 & 5.00 & $3.44^{*}$ & 0.76 & 801.00 \\
\hline
\end{tabular}

$1.80=$ Disagree $\quad 2.60=$ Undecided $* 3.40=$ Agree 


\section{Investigation of the Relationship between the Attitudes of Syrian Asylum}

Seekers and the Independent Variables

As seen in Table 4 below, there is a statistical relationship between some of the independent variables (their demographic characteristics) and Syrian asylum seekers' average attitude scores about their situation in Turkey.

Table 4. Pearson Correlation Coefficient of Attitudes of the Sample Group According to Their Demographic Variables $(n=233)$

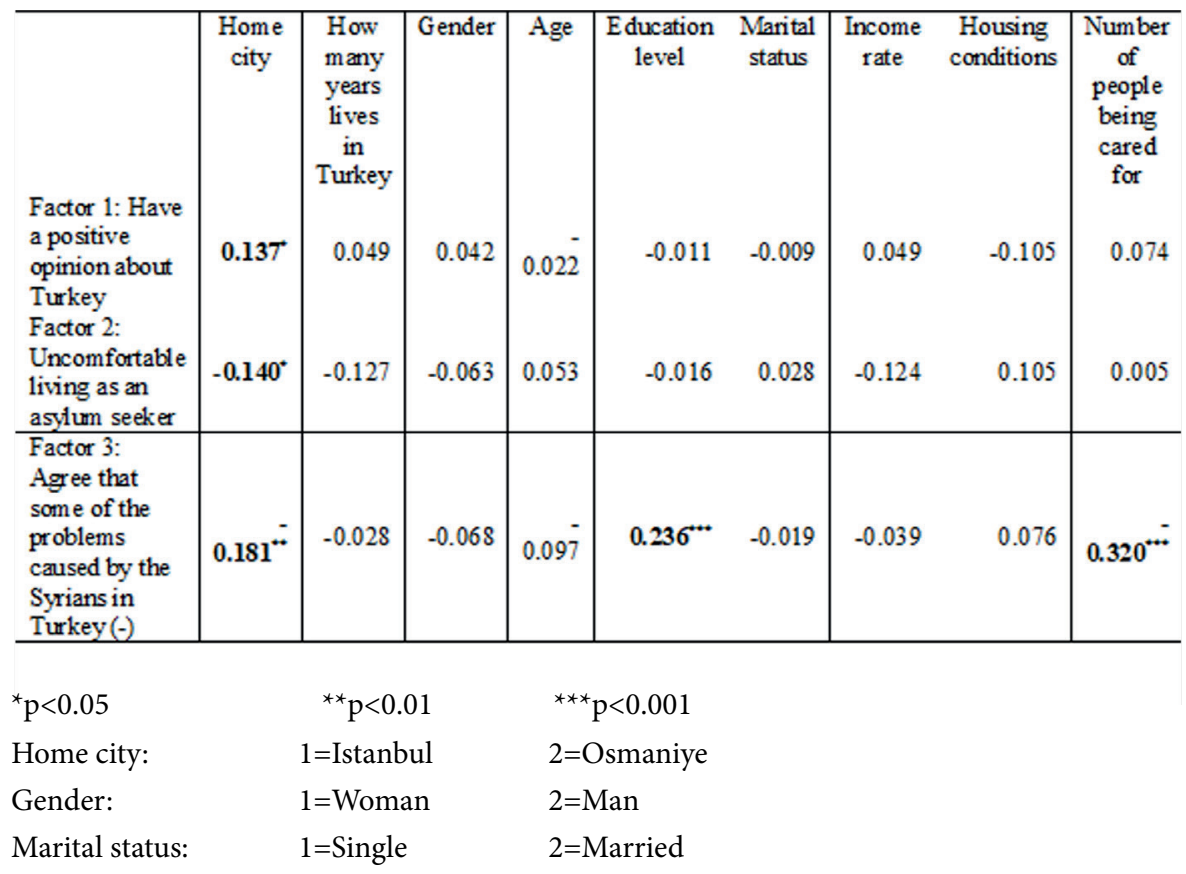

According to Table 4, Syrians who were living in the camps in Osmaniye have more positive attitude about Turkey than Syrians who were living with their own means in İstanbul ( $\mathrm{r}=0.137 ; \mathrm{p}<0.05)$. But Syrians who were living in Istanbul are more disturbed as an asylum seeker $(r=-0.140 ; p<0.05)$ and they seriously don't accept about the problems that arise from the Syrians in Turkey more than Syrians who were living in Osmaniye $(r=-0.181 ; \mathrm{p}<0.01)$. 
In addition, the sample group of highly educated ones $(\mathrm{r}=0.236 ; \mathrm{p}<0.001)$ and who are responsible to take care of less people $(\mathrm{r}=-0.320 ; \mathrm{p}<0.001)$ absolutely didn't accept the problems that arise from the Syrians in Turkey.

The findings supported the hypotheses regarding the city of residence, education level of respondent and the number of people being cared for $(1,4$, $8)$; but did not support the other hypotheses $(2,3,5,6,7)$.

\section{DISCUSSION AND CONCLUSION}

In this section, the information and findings about the Syrian asylum seekers are discussed under the subtitles in the light of the literature.

\section{Reasons of Syrians' Asylum to Turkey}

The main reason why Syrian asylum seekers left their home country was mostly life threatening $(76.0 \%)$. This was followed by keeping the family together $(18.0 \%)$, the economic reasons (10.3\%), avoiding work (5.6\%), the transition to European Union countries (3.9\%) and going to university (3.0 \%) (see Table 1). When other researches on this subject are examined, life safety and economic reasons are at the top of the list (Apak, 2014; Kariman, 2015; Özkarsl1, 2014). Especially in a research conducted by Özkarslı (2014) in the province of Mardin, 65 percent of Syrian asylum seekers' reason of coming to Turkey was finding a job and 28 percent of the male population in particular evaluated the job opportunities directly. As a result, these studies support the findings of our research.

As it is seen in Table 1, the second reason for the Syrians to leave their country were "to keep the family together" (18.0\%). As a matter of fact, more 
than half of the respondents came to Turkey with their relatives (54.5\%). Also the majority of the asylum seekers who came with their relatives stated that their relatives were effective in adapting to the country (89.8\%) (see Table 1). Likewise in Apak's (2014) survey, more than half of the participants (54.5\%) stated that they had relatives in Mardin. Also 34.1\% of respondents immigrated to Turkey, because their relatives were living in the same country. Already in the case of immigration, it is important to have relatives or fellow citizens in that area in order to be able to easily adapt and be in solidarity. This situation causes immigrants to gather in certain neighborhoods in cities (Erdem, 2006: 335).

\section{Problems Syrians Live in Turkey}

One of the major problems experienced by Syrians in our country is the problem of "subsistence and housing" that the state aid and free services are not enough for the crowded families who were living outside the camps. As a matter of fact, in the analysis of needs in Istanbul, it was determined that Syrian asylum seekers has the most basic human needs. These needs are nutrition, health, shelter, education, hygiene, new-born-mother needs, safety, cleaning, warming and non-food products (Acar, et al., 2015). In our study 0.9 $\%$ of the asylum seekers reported that they had problems of subsistence and housing (see Table 1). The reason for the low number of living and housing problems is that more than half of the sample group (58.4\%) reside in camps under state protection.

Syrian asylum seekers also have difficulties at university; this may be due to both the language problem and the educational system difference between the two countries. As a matter of fact, in our study, the majority of the people who lived problem; experienced difficulty in being in different languages (3.0\%) 
and in different cultures $(2.2 \%)$. This was followed by "negative words about asylum seekers" (0.9\%), "the problem of subsistence and housing" (0.9 $\%)$, "difficulty in university" (0.4\%), "being harassed in the minibus" (0.4\%), and "the problem with the host" $(0.4 \%)$ (see Table 1$)$.

In addition, the education level of the asylum seekers in our country is low and it is not possible for them to find jobs as qualified staff; that forces their living conditions. But in our study $32.2 \%$ of our respondents were high school graduates and $15.9 \%$ were university graduates because of Syrians who live in İstanbul were chosen from TÖMER (see Table 1). In other studies, it was found that almost half of the Syrian asylum seekers were primary and lower educated, and very few were university graduates and the total level of education was low (ORSAM Raporu, 2015b; Y1ld1z, 2013). It has been observed that the number of students in schools in the cities where the Syrians settled has increased. Although the training opportunities provided by Turkey, there are some problems related to bilingual education and some Syrian children's school absenteeism. As regards asylum-seekers, problems such as teacher training, provision of educational curricula / materials, type of education (mixed, male / female education), adaptation problem, economic concerns and child labor remain. Asylum seekers who do not speak Turkish, especially in high school age, try to contribute financially to their families by not going to school (Korkmaz, 2016, p. 98). Also the cultural differences with the Syrians are seen in the work life (for example, they don't want to work after 3 o'clock pm; men don't want to work after the age of 45-50 years, because of that they send their school age sons to work). Differences in working ethics and culture make it difficult to keep up with the length of work hours and work tempo. This situation opens up a number of different problems, such as child labor, child neglect and abuse (KTO, 21 Nisan 2017, p.5). In other words, it causes a generation with low levels of education from father to son and permanent poverty. 
The Turkish state needs to plan how to benefit from this unqualified manpower. In this context, measures should be taken to ensure the adaptation of school-aged Syrian children to schools. For example, it should be taken into consideration that having more than five Syrian students in each class complicates Turkish learning. For this purpose, Syrian students should be regularly distributed to each school and provided service for students. In addition, children with peer bullying should be identified in schools and awareness should be established in students, teachers, school management and families regarding peer bullying by guidance counselors and school social workers.

In this study, while other problems are not mentioned by asylum seekers but determined in other studies: In Doğan's (2011) study among the Syrians, those of different religions thought they were subject to double discrimination. In Özkarsli's (2014) survey, 33.0\% of Syrians stated that local people reacted to them because they did not fight for their country, and $26.0 \%$ said that local people reacted because they worked cheaper (as they lower the value of labor in the labor market)

It is very important to take steps to facilitate the adaptation of immigrants to the country by giving them the opportunity to prevent their exploitation in various ways and to protect their own culture. Women and children, particularly vulnerable to sexual and labor exploitation, should be considered in a separate category. In order to eliminate these negative effects, special supportive / protective measures should be developed for women and children. For example, women and children living in distress can be provided with shelter. In addition, psychosocial support should be offer to Syrian asylum seekers to erase the traces of violence experienced in their country and to deal with problems which they experience in Turkey (Yllmaz, 2014, p.1698-1699). 


\section{Syrians' Attitudes about Turkey}

According to the results of the research sample group has a positive opinion about Turkey in general $(\overline{\mathrm{X}}=3.40)$ (see Table 3). However, the aslum seekers living in the camps in Osmaniye are more satisfied than the refugees living in Istanbul with their own means $(\mathrm{p}<0.05)$ (see Table 4$)$. This difference in satisfaction may be due to the fact that the asylum-seekers living in the camp can benefit more from their accommodation and state aids. Also the Syrians living in the camps, to have more positive attitudes about Turkey may be due to less exposure to second culture. Thus in other studies, it has been determined that the presence of acquaintances belonging to the same language, religion, ethnic origin, common historical ties, kinship ties, or members of the same tribe (ethnic group) and the presence of common cultural characteristics play an important role in the adoption of the city and establishing relations with the natives (Deniz and Etlan; 2009; Özkarsl1, 2014).

Similarly in some other studies it found that Syrian asylum seekers living in the camp (Güneş, 2013) or living outside camps (Apak, 2014; Erdoğan, 2015; Deniz et al., 2016a; Karasu, 2016; Kaya, 2015; Kaypak and Bimay, 2016) were satisfied to be in Turkey. The Syrians reported that they pleased with the community's general attitude with regards to them (Özkarsl1, 2014) and they had no problems of adaptation because they shared the same religious structure (Özmen, 2012: 81; Apak, 2014). There were also those who expressed help from the Turks (Kariman, 2015). In addition, among the asylum seekers, the Turkmens perceive the assistance provided to them as the brotherly sharing of the same religion and nationality. Also support for participation in the workforce by providing vocational courses of asylum seekers has caused them to think positively about Turkey (like giving "greenhouse courses within the scope of emergency support project to support crop production") (Habertürk, 25 Eylül 2018). In terms of psychological support and attention, the Minister 
of Interior visits some families living in the Temporary Housing Center at home (Star, 28 Ocak 2018).

\section{Discomfort from Living as an Asylum Seeker}

According to the research findings, Syrians who are residing in Istanbul with their own means feel more discomfort than the asylum seekers living in the camps in Osmaniye ( $\mathrm{p}<0.05)$ (see Table 4). Although Syrians who are residing in Istanbul can benefit from nutrition, shelter, health, education and other social benefits within the scope of the "Temporary Protection Regulation" 2014/6883, it is obvious that they feel more discomfort than living as an asylum seeker in the camps in Osmaniye because living conditions are more challenging in big city conditions. In fact, some studies have found that Syrian asylum seekers have problems with fundamental rights (citizenship, working rights, residence permits) and public rights (municipal, health, education, social, political) (Özdemir, 2017; Arslan et al., 2017; Tunç, 2015; Sandal et al., 2016; Paksoy and Şentöregil, 2018).

Also in some other researches, while the majority of Syrians was pleased to live in Turkey but they want to return back when conditions improve in their country (Boyraz, 2015; Güneş, 2013; Özkarsl1, 2014). According to the report of the Center for Socio-Political Field Studies (2019), 66\% of the asylum seekers living in the cities on the Syrian border want to return to their country (Sosyo Politik Saha Araştırmaları Merkezi, 2019). Because the Syrians in our country often have problems in basic services such as housing, health and education (Gün, 2011: 272; ORSAM Raporu, 2015a: 16; Ataman, 2015: 29). In addition, Syrians have difficulty in learning Turkish as an asylum seeker, adapting to a foreign culture and communicating with Turks. Also, the supporters of the pro-government and extremist groups who initiated the 
civil war in Syria have fostered the separation between the two communities by organizing aggressive campaigns targeting Syrian asylum seekers on social networking sites. The purpose of these groups is to make Syrians angry against the Turkish people and the government through false news and statements. Thus, they want to encourage Syrians to rebel against the Turkish people and government by portraying the Turks as colonists and exploiters (İNSAMER 2019). Such incitement campaigns increase the anxiety and insecurity of Syrians. Some Turkish media outlets exaggeratedly publish individual events / crimes involving Syrians (beating children, leaving children alone at home, violence against women and so on) and blame them for every problem (like Hakan, 8 Şubat 2018). On the other hand, the positive aspects and successes of the Syrians are ignored or not properly reflected. Events such as the arrest and deportation of large numbers of Syrians without official identity documents also contribute to the spread of such negativities. This situation adversely affects the cohesion between the two peoples (Deniz et al., 2016b: 32-33; Erdoğan, 2015: 120-121).

As a result, the problems arising from the difference of language, culture and lifestyle between asylum seekers and local people in Turkey are an important reason for the reactions of local people (ORSAM Raporu, 2015a: p.16). In fact, according to Yaşar's (2014) study, it is noteworthy that although Syrians living in the border provinces of the region have a cultural identity very close to the region, local people express serious cultural differences between themselves and asylum seekers and call Syrians incompatible. In addition, there is a perception among the people of the region that the Syrians do not pay attention to cleanliness, are lazy, do not fulfill their promise, make a lot of noise and are rude (Erdoğan, 2015: 117). 


\section{Disagree that Some of the Problems Caused by the Syrians in Turkey}

In general, the sample group did not attend the problems caused by the Syrians in Turkey $(\overline{\mathrm{X}}=3.44)$. Especially those living in Istanbul $(\mathrm{p}<0.01)$, those with a high level of education $(\mathrm{p}<0.001)$ and the ones who has responsible to take care of less people ( $\mathrm{p}<0.001)$ absolutely didn't accept the problems that arise from the Syrians in Turkey. Because those who have a higher education level and who are responsible for the care of fewer people can be more defensive because they are less dependent on the protection of the Turkish State. In addition, the Syrians who living in large cities with limited support from the state and with their own means are more likely to communicate to local people than those living in the camps and may be more defensive because they face discrimination from time to time (Aksoy, 2012; Biner and Soykan, 2016; Kömürcü et al., 2011; Tatlılığlu, 2012; Yaşar, 2014). Also Center for SocioPolitical Field Studies (2019) reported that 15 percent of Syrians who lives in the cities on the Syrian border faced a negative situation such as discrimination and exclusion (Sosyo Politik Saha Araştırmaları Merkezi, 2019).

In fact, in the first years of migration, the society evaluated Syrian asylum seekers within the framework of basic values such as neighborhood and brotherhood. They helped Syrians who are in a difficult situation and exhibited a positive attitude with regards to them (Erdoğan, 2015, Karasu, 2016). Among Turkish citizens, there were those who argued that Syrian asylum seekers were religious brothers and guests, and that accepting them was a duty of humanity (Erdoğan, 2014; Gözübüyük Tamer, 2016) and that asylum seekers should be given the opportunity to receive education (Erdoğan, 2014; Göde et al. 2014). There are also those who have reported that they helped Syrians with goods (food, clothing, etc.) and cash (money) (Güçer et al., 2013: 24; Atasoy and Demir, 2015; Döner, 2016; Topkaya and Akdağ, 2016; Kabaklı Çimen and Ersoy Quadir, 2018). 
Besides that, because of the instability in Syria, the continuing unresolved turmoil and the asylum seekers' prolonged duration of live in Turkey, some controversies and problems come to the fore in Turkish society. These debates and problems change the attitudes of local people with regards to asylum seekers. In other words, it can be said that this emotional change in the public is caused by Syrians' prolonged of stay and the political process that maintains the uncertainty.

Indeed, the "Refugee Survey" report by BAREM (2016), the positive perception with regards to refugees in Turkey $29 \%$, while the negative perception is reported to be $64 \%$ (BAREM, 2016). According to the report of the Center for Socio-Political Field Studies (2019), 83\% of the citizens living in the cities on the Syrian border reported that their security level decreased due to Syrians and $77 \%$ of them said that they don't want Syrians in their country (Sosyo Politik Saha Araştırmaları Merkezi, 2019). Kabaklı-Çimen and ErsoyQuadir (2018) found that university students had negative thoughts about Syrian refugees. In addition, the vast majority of citizens of the Republic of Turkey do not want Syrian asylum seekers to be granted citizenship for fear that they will stay here and become economically burdensome (BAREM, 2016; Çiftçi, 2018; Erdoğan, 2014, 2015; Gülyaşar, 2017: p.678, Özdemir, 2017, p.132; Saçan et al., 2017: 28; Sandal et al., 2016: p.480; Paksoy and Şentöregil, 2018: p.237; Tunç, 2015: p.58; Tümtaş, 2018: p.26; Varyans Araştırma Danışmanlık Şirketi, 2016). In the research findings obtained: 83\% of Turkish people didn't approve the citizenship issue of Syrians (Metropoll Araştırma Şirketi, 2016). Local people believe that Syrians lead to major problems in Turkey (Erdoğan, 2014) and they have dispute with asylum seekers (Nasirova, 2014). They don't want to help Syrians (Erdoğan, 2014) or they were undecided on this issue (Ersoy Quadir and Kabaklı Çimen, 2018). Also they don't want to be neighbor with one of the Syrians (Erdoğan, 2014; Sosyal Politika Saha Araştırmaları 
Merkezi, 2019); they want from government to create a buffer zone on the territory of the border to accommodate the Syrians there (Demir, 2015; Gözübüyük Tamer, 2016).

Other negative thoughts expressed by the Turkish people: Syrian asylum seekers are triggering terrorism and creating security problems (Türkoğlu, 2011; Erdoğan, 2014; Göde et al., 2014; Ercan, 2016; Çetin 2017); the rights and opportunities granted to them are numerous (Karasu, 2016; Karataş, 2015; Topkaya and Akdağ, 2016); they adversely affect the environment and healthy living (Karadeniz, 2016; Kaypak and Bimay, 2016); some Syrians are disturbing the public by engaging in immoral crimes such as theft, begging, violence, prostitution and smuggling (Boyraz, 2015; Erdoğan, 2014-2015; Döner, 2016); they bring economic burden to the country with population growth and increase the cost of living (such as the increase in house prices and rents) (Atasoy and Demir, 2015; Çetin 2017; Döner, 2016; Ercan, 2016; Erdoğan, 2014; Karasu, 2016; Kaypak and Bimay, 2016; Transatlantik Eğilimler 2013 Raporu; ORSAM Raporu, 2015a; Topkaya and Akdağ, 2016); they increase unemployment and job loss (Erdoğan, 2014-2015; ORSAM Raporu, 2015b; Atasoy and Demir, 2015; Döner, 2016; Karasu, 2016; Kaypak and Bimay, 2016; Topkaya and Akdağ, 2016; Sosyo Politik Saha Araştırmaları Merkezi, 2019).

Whereas the expectations of asylum seekers from the society in this process; enhanced psychological well-being, economic support and independence, the power to control and lead their lives, the continuation of culture, language and religion, and communication with the host society (UNHCR, 1994, p.14). In this context, the fact that the Association of Refugees published the right- 
known mistakes about Syrian asylum seekers in the media is an effective practice in calming the local people (Some of the examples that the Syrians did not receive salary from the state or that the Syrian tradesmen gave taxes to the state or that the Syrians did not enter the university they wanted without examination, and that not every Syrian student in the university received a scholarship) (Mülteciler Derneği, 10 Aralık 2019).

As Yllmaz $(2014$, p.1698, 1699) states, first of all, migration is a social event. Today, the biggest mistake of the states is that the migration is considered as "security" oriented. Policies on international migration need to be examined in three dimensions, namely "control", "international relations" (the relationship between sovereignty, national security and foreign policy and international migration) and the "harmonization of immigrants" (the impact of immigration on citizenship, political developments). In other words, the development of policy regarding to only one of these dimensions will not be sufficient to address the issue of international migration. It will be much more appropriate to address the problems that arise with the migration process through multifaceted policies and approaches. 


\section{REFERENCE}

Abu-Bader, S.H. (2011). Using Statistical Methods in Social Science Research: With a Complete SPSS Guide. (Second Edition) New York: Oxford University Press.

Acar, C., Sandıkl1, B., Mücaz, M., Ülger, Z., Torun, P. (2015). İstanbul'da Yaşayan Geçici Koruma Altındaki Suriyeliler: İhtiyaç Analizi Raporu. İstanbul: Bezmialem Vakıf Üniversitesi Tıp Fakültesi Halk Sağlığı Anabilim Dalı Yayını.

Akgül, R., Polat Uluocak, G. (2000). Evlilikte Etkili İletişim ve Problem Çözme: Bir Toplum Merkezindeki Kadınlarla Gerçekleştirilen Grup Çalışması. Aile ve Toplum Eğitim-Kültür ve Araştırma Dergisi, 6 (23), 9-22.

Aktaş, A. (2016). Türkiye’de Yaşayan Suriyeli Kadın Mülteciler: Kilis Örneği, (Unpublished Master's Thesis). Bilgi University, Social Sciences Institute, İstanbul.

Aksoy, Z. (2012). Uluslararası Göç ve Kültürlerarası İletişim. Uluslararası Sosyal Araştırmalar Dergisi, 5(20), 292-303.

Angay, H. (2012). Doğu ve Güneydoğu İllerinden İzmir’e Göç Eden Ailelerin Çocuklarının Okul Sorunlarının İncelenmesi, (Unpublished Master's Thesis). Ege University Social Sciences Institute, İzmir.

Apak, H. (2014). Suriyeli Göçmenlerin Kente Uyumları: Mardin Örneği. Mukaddime, $5(2), 53-70$.

Arslan, İ., Bozgeyik, Y., Alancıoğlu, E. (2017). Göçün Ekonomik ve Toplumsal Yansımaları: Gaziantep’teki Suriyeli Göçmenler Örneği, İlahiyat Akademi Dergisi, 3 (4): 129-148.

Ary, D., Jacobs, L. C., Razavieh, A., Sorensen, C. K., (2009). Introduction to Research in Education. (8th Edition). United States: Wadsworth Cengage Learning.

Ataman, H. (2015). Mülteci mi, sığınmacı mı, misafir mi? Görüş Dergisi, (88), 26-33.

Atasoy, A., Demir, H. (2015). Suriyeli Sığınmacıların Kırıkhan’a (Hatay) Etkileri. Uluslararası Sosyal Araştırmalar Dergisi, 8 (38), 457-470.

Barın, H. (2015). Türkiye'deki Suriyeli Kadınların Toplumsal Bağlamda Yaşadıkları Sorunlar ve Çözüm Önerileri. Göç Araştırmaları Dergisi, 1(2), 10-56.

BAREM. (2016). Mülteciler sorunu Dünya’yı böldü. Retrieved April 25, 2019 from the http://www.barem.com.tr/multeciler-sorunu-dunyayi-boldu/) 
Bayraktar, E.B. (1999). Köyden Kente Göç Olgusuna Bağlı Olarak Diyarbakır İl Merkezindeki İlköğretim Okullarında Ortaya Çıkan Sorunlara İlişkin Öğretmen Algıları (Unpublished Master's Thesis). Dokuz Eylül University Institute of Education Sciences, İzmir.

Biner, Ö., Soykan, C. (2016). Suriyeli Mültecilerin Perspektifinden Türkiye’de Yaşam. AB Türkiye Delegasyonu Sivil Düşün Programının desteği ile yürütülen Çeşitlilik ve Stratejik Davalama Ağı Projesi. İstanbul: Mülteci-Der ve Sivil Düşün Yayını.

Bingöl, A.S. (2006). Almanya ve Hollanda'da Türk Göçmen İşçi Çocuklarına Dönük Eğitim Politikaları ve Uygulamaları (Unpublished Master's Thesis). Gazi University Institute of Education Sciences, Ankara.

Boyraz, Z. (2015). Türkiye'de Göçmen Sorununa Örnek Suriyeli Mülteciler. Zeitschrift für die Welt der Türken (Journal of World of Turks), 7 (2), 35-58.

BMMYK (Birleşmiş Milletler Mülteciler Yüksek Komiserliği). (1994). Kentsel Mülteciler İçin Sosyal Hizmetler, Cenevre: BMMYK Yayınları.

Çetin, S. (2017). İzmir'deki Yerel Halkın Suriyeli Sı̆̆ınmacılara Yönelik Algısı, (Unpublished Master's Thesis). Afyon Kocatepe University Social Sciences Institute, Afyonkarahisar.

Çiftçi, H. (2018). Türkiye Cumhuriyeti Vatandaşlarının Suriyeli Sığınmacılara Yönelik Tutum, Alg1 ve Empatik Eğilimlerinin Analizi, İnsan ve Toplum Bilimleri Araştırmaları Dergisi, 7(3), 2232-2256.

Demir, O. Ö. (2015). Göç Politikaları, Toplumsal Kaygılar ve Suriyeli Mülteciler. Ankara: Global Politika ve Strateji Yayını.

Deniz, O., Etlan, E. (2009). Kırdan kente göç ve göçmenlerin uyum süreci üzerine bir çalışma: Van örneği. Uluslararası İnsan Bilimleri Dergisi. 6(2), 472- 498.

Deniz, A. Ç., Hülür, A. B., Ekinci, Y. (2016a). Göç, strateji ve taktik: Suriyeli Sığınmacıların Gündelik Hayat Deneyimleri. Uluslararası Sosyal Araştırmalar Dergisi, 9 (42), 1077 1087.

Deniz, A.Ç., Ekinci, Y., Hülür, A.B. (2016b). Suriyeli Sığınmacıların Karşılaştığı Sosyal Dışlanma Mekanizmaları, Sosyal Bilimler Araştırma Dergisi, 14(27),17-40.

Doğan, M. (2011). Türkiye'de Mültecilerin ve Sığınmacıların Uluslararası Hukuk Çerçevesindeki Temel Haklarının Sağlanması (Unpublished Master's Thesis). Çanakkale Onsekiz Mart University Social Sciences Institute, Çanakkale. 
Döner, H. (2016). Suriyeli Göçmenlerle Yaşanan Sorunlar Üzerine Sosyolojik Bir Araştırma: Hatay İli Örneği (Unpublished Master's Thesis ). Fırat University Social Sciences Institute, Elâzı̆̆.

Durgel, E., Yağmurlu, B. (2014). Türk Göçmen Ailelerde Sosyalleştirme Hedefleri ve Ana Babalık: Okul Öncesi Döneme Detaylı Bakış. Türk Psikoloji Yazıları, 17 (34), Aralık, 3-12.

Emmen, R., Malda, M., Mesman, J., Ekmekci, H., Van Ijzen $\neg$ doorn, M. (2012). Sensitive Parenting as a Cross-Cultural İdeal: Sensitivity Beliefs of Dutch, Moroccan, and Turk $\neg$ ish Mothers in the Netherlands. Attachment \& Human Development, 14; 601-619.

Ercan, Ö. (2016). Medyanın Kitleleri Etkilemedeki Gücü: Suriye Savaşı Üzerinden Yazılı Basın İncelemesi (Unpublished Master's Thesis). Bahçeşehir University Social Sciences Institute, İstanbul.

Erdem, T. (2006). Yoksulluk. Feodaliteden Küreselleşmeye Temel Kavram ve Süreçler. Tevfik Erdem (Ed.), (Birinci Baskı), Ankara: Lotus Yayınları.

Erdoğan, M. M. (2014). Türkiye'deki Suriyeliler: Toplumsal Kabul ve Uyum Araştırması. Ankara: Hacettepe University Migration and Politics Research Center Publication.

Erdoğan, M. M. (2015). Türkiyedeki Suriyeliler Toplumsal Kabul ve Uyum. İstanbul: İstanbul Bilgi Üniversitesi Yayınları.

Ersoy Quadir, S., and Kabaklı Çimen, L. (2018). Türk vatandaşlarının Suriyeli sığınmacılarla ilgili görüşleri (Konya ili örneği). Üçüncü Sektör Sosyal Ekonomi, 53(2), 327-345.

Ghazali, D. (2008). Kesahan dan Kebolehpercayaan Dalam Kajian Kuantitatif dan Kualitatif. Jurnal Institut Perguruan Islam. April.

Göde, B., Taşgın, C., Uysal, E., Meral, M.R., Çetinkaya, M., Çakır, R.C., ve Aydın, Ş. (2014). Suriyeli Sığınmacılar Raporu İstanbul Örneği. İstanbul: İstanbul Fikir Enstitüsü Yayını. Retrieved 10.01.2020, from the https://www.academia.edu/9690038/ Suriyeli_S\%C4\%B1\%C4\%9F\%C4\%B1nmac\%C4\%B1lar_Raporu).

Gözübüyük T. M. (2016). Trabzon Kamuoyunun Geçici Koruma Kapsamındaki Suriyelilere Bakış Açısı (Türkiye-Trabzon örneği). Karadeniz Araştırmaları Enstitüsü Dergisi, 2 (2), 180-211. 
Karakuş, E. (2006). Göç Olgusu ve Eğitime Olumsuz Etkileri (Sultanbeyli Örneği,) (Unpublished Master's Thesis). Sakarya University Social Sciences Institute, Sakarya. Karataş, M. (2015). Türk yazılı basınında Suriyeli Sığınmacılar ile Halk Arasındaki İlişkinin İncelenmesi. Göç Araştırmaları Dergisi, 1(2), 112-151.

Karasu, M. A. (2016). Şanlıurfa'da Yaşayan Suriyeli Sığınmacıların Kentle Uyum Sorunu. Süleyman Demirel Üniversitesi İktisadi ve İdari Bilimler Fakültesi Dergisi, 21, 9951014.

Karadeniz, M. (2016). Kilis’te Yaşayan Suriyeli Sığınmacıların İl Ekonomisine Etkisi, (Unpublished Master's Thesis). Kilis 7 Aralık University Social Sciences Institute, Kilis.

Kariman, S. (2015). Türkiye’ye Göç Eden Mültecilerin Sosyal Hayata Uyum Sürecinin İncelenmesi: Isparta Örneği (Unpublished Master's Thesis). Süleyman Demirel University Social Sciences Institute, Isparta.

Kaya, M. (2015). Komşuda Misafirlik: Suriyeli Sığınmacılarca Kurulmuş Mülteci Derneklerinin Perspektifinden Türkiye'de yaşamak. International Journal of Social Science, 39, 263-279.

Kaypak, Ş., and Bimay, M. (2016). Suriye Savaşı Nedeniyle Yaşanan Göçün Ekonomik ve Sosyo- Kültürel Etkileri: Batman örneği. Batman Üniversitesi Yaşam Bilimleri Dergisi, 6, 84-110.

Koçanc1, M. (19 Şubat 2018). Antalya Haberleri: Büyük Şehirlerdeki Suriyeli Gettoları Endişesi. Hürriyet Gazetesi, Retrieved May 29, 2019 from the https://www.haberler. com/buyuk-sehirlerdeki-suriyeli-gettolari-endisesi-2-10579982-haberi/)

Korkmaz, A. (2016). Suriyeli Sığınmacılardan Kaynaklanan Sorunlar ve Çözüm Önerileri, Akademik Hassasiyetler, 3(6), 83-116.

Kömürcü Y, Özsoy R, Çobanoğlu A. (2011). Kadın Sığınmacılar: Uluslararası Göçün Sessiz Tanıkları. Onlar Bizim Hemşehrimiz: Uluslararası Göç ve Hizmetlerin Kültürlerarası Açılımı. E Esen, Z Yazıcı (Eds). Ankara: Siyasal Kitabevi.

KTO (Karatay Üniversitesi). (21 Nisan 2017). Konyada yaşayan Suriyeliler: güncel sorunlar ve çözüm önerileri çalıştayı sonuç raporu. Retrieved August, 31, 2019 from the https://www.karatay.edu.tr/duyurular/haberDetay.php?haber_id=1253

MAZLUMDER. (2014). Kamp Dıı̧ında Yaşayan Suriyeli Kadın Sı̆̆ınmacıların Raporu. İnsan Hakları ve Mazlumlar İçin Dayanışma Derneği Yayını. Retrieved April, 10, 2019 from the 
http://istanbul.mazlumder.org/tr/main/yayinlar/yurt-ici-raporlar/3/mazlumder-kampdisinda-yasayan-suriyeli-kadin/1116)

Metropoll Araştırma Şirketi. (07 Temmuz 2016). Anket sonucuna göre Suriyelilere vatandaşl1k verilmesine halk ne diyor? Metropoll Araştırma Şirketi’nin Mart 2016 Araştırması, Retrieved August, 11, 2019 from the http://www.sonsayfa.org/guncel/ anket-sonucuna-gore-suriyelilere-vatandaslik-verilmesine-halk-ne-diyor-1359)

Mülteciler Derneği. (10 Aralık 2019). Suriyelilerle İlgili Doğru Bilinen Yanlışlar. Mülteciler Derneği. Retrieved January, 17, 2020 from the https://multeciler.org.tr/suriyelilerleilgili-dogru-bilinen-yanlislar/)

Mülteciler Derneği. (30 Aralık 2019). Türkiye'deki Suriyeli Sayısı Aralık 2019. Retrieved January, 10, 2020 from the https://multeciler.org.tr/turkiyedeki-suriyeli-sayisi/).

Nasirova, A. (2014). Şartlı Mültecilerin Yerel Halka Yönelik Görüşleri: Afyonkarahisar Örneği ( Unpublished Master's Thesis). Hacettepe University Social Sciences Institute, Ankara.

Oral, M., Tuncay, T. (2012). Ruh Sağlığı Alanında Sosyal Hizmet Uzmanlarının Rol ve Sorumlulukları. Toplum ve Sosyal Hizmet, 23 (2), 93-114.

ORSAM (Ortadoğu Stratejik Araştırmalar Merkezi) Raporu. (2015a). Suriyeli Sığınmacıların Türkiye’ye Etkileri. (Haz: Oytun, O. ve Gündoğar, S. S.) Ankara: ORSAM- TESEV Yayını (No: 195) (ISBN: 978-605-4615-95-7). Ocak 2015, Retrieved September, 06, 2019 from the https://www.tesev.org.tr/tr/research/ suriyeli-siginmacilarin-turkiyeye-etkileri/

ORSAM (Ortadoğu Stratejik Araştırmalar Merkezi) Raporu. (2015b). Suriyeli Mültecilerin Türkiye’ye Ekonomik Etkileri: Sentetik Bir Modelleme. (Haz: Öztürkler, H., ve Göksel, T.) Ankara: ORSAM Yayını (No: 196) (ISBN: 978-605-4615-98-8) Ocak 2015, Retrieved September, 06, 2019 from the http://www.orsam.org.tr/eski/tr/ trUploads/Yazilar/Dosyalar/201519_rapor196tur.pdf.

Önen, C, Güneş, G., Türeme, A., and Ağaç, P. (2014). Bir Mülteci Kampında Yaşayan Suriyelilerde Depresyon ve Anksiyete Durumu. Akademik Sosyal Araştırmalar Dergisi, 6, 223-230.

Özer, S., and Şirin, S. R. (2013) Suriyeli Mülteci Çocuklar-Saha Araştırması Sonuç Raporu. İstanbul: Bahçeşehir Üniversitesi Yayını, Retrieved May, 15, 2019 from the www.gib. icisleri.gov.tr/default_B0.aspx?id=180) . 
Özdemir, E. (2017). Suriyeli mültecilerin Türkiye'deki algıları. Journal of Defense Sciences, $16(1), 115-136$.

Özkarslı, F. (2014). Suriye’den Türkiye’ye Göç ve Suriyelilerin Enformel İstihdamı (Mardin Örneği) (Unpublished Master's Thesis). Artuklu University Social Sciences Institute, Mardin.

Özmen, N. (2012). Çokkültürlü Toplumda Sosyal Entegrasyon ve Din. İstanbul: Çamlıca Yayınları.

Paksoy, A. F., Şentöregil, M. (2018). Türk basınında Suriyeli sığınmacılar: İlk beş yılın analizi (2011-2015). Selçuk Üniversitesi İletişim Fakültesi Akademik Dergisi, 11(1), 237-256.

Polat-Uluocak, G. (2009). İç Göç Yaşamış ve Yaşamamış Çocukların Okulda Uyumu. Dokuz Eylül Üniversitesi Buca Eğitim Fakültesi Dergisi, 26, 26-44.

Saçan, S., Cizdan G., Tabak Hikmet , D. (2017). Aydın halkının Suriyeli Göçmenlere Yönelik Bakış Açısının İncelenmesi. Adnan Menderes Üniversitesi Sağlık Bilimleri Fakültesi Dergisi, 1(1), 28-38.

Sandal, E. K., Hançerkıran, M., Tıraş, M. (2016). Türkiyedeki Suriyeli Mülteciler ve Gaziantep İlindeki Yansımaları, Gaziantep University Journal of Social Sciences, 15(2), 461-483.

Sosyo Politik Saha Araştırmaları Merkezi (2019). Sınır Kentlerinde Mülteciler ve Yerleşik Halk Arasındaki ilişki, Uyum ve Kabul Problemleri Araştırma Raporu. Retrieved January 17, 2020 from the https://sahamerkezi.org/sinir-kentlerinde-multecilerve-yerlesik-halk-arasindaki-iliski-uyum-ve-kabul-problemleri-arastirmasiocak-2019/)

Star. (28 Ocak 2018). İçişleri Bakanı Soylu, Osmaniye’de. Star Gazetesi. Retrieved January 17,2019 from the, https://www.star.com.tr/yerel-haberler/icisleri-bakani-soyluosmaniyede-207394/)

Tatlılıoğlu, D. (2012). Göç sosyolojisi açısından hicret. İstanbul: Asitan Yayını.

Teber, S. (1993). Göçmenlik Yaşantısı ve Kişilik Değişimi. Ortadoğu Verlag, Oberhausen.

Topkaya, Y., Akdağ, H. (2016). Sosyal Bilgiler Öğretmen Adaylarının Suriyeli Sığınmacılar Hakkındaki Görüşleri (Kilis 7 Aralık Üniversitesi Örneği). Çankırı Karatekin Üniversitesi Sosyal Bilimler Enstitüsü Dergisi, 7 (1), 767-786. 
TÜIKK (Türkiye İstatistik Kurumu). (01 Mart 2019). TÜİK verileri açıladı: İște 2018 Evlenme ve Boşanma İstatistikleri. Retrieved December, 15, 2019 from the https://yenikapihaber.com/tuik-verileri-acikladi-iste-2018-evlenme-ve-bosanmaistatistikleri-101700h.htm)

TÜIK (Türkiye İstatistik Kurumu). (02 Mart 2018) Türkiye İstatistik Kurumu (TÜIK), 2017 yll evlenme ve boşanma istatistiklerini açıkladı. Retrieved January 15,December 2019 from the, https://www.trthaber.com/haber/yasam/evlenme-bosanmaistatistikleri-353356.html

Transatlantik Eğilimler. (2013). Transatlantic Trends Key Findings 2013, The German Marshall Fund of the United States Strengthening Transatlantic Cooperation. Retrieved March 15, 2019 from the http://trends.gmfus.org/files/2013/09/TT2013Key-FindingsReport-in-Turkish.pdf) .

Tunç, A. Ş. (2015). Mülteci Davranışı ve Toplumsal Etkileri: Türkiyedeki Suriyelilere İlişkin Bir Değerlendirme, TESAM Akademi Dergisi, 2 (2), 29-63.

Tümtaş, M. S. (2018) Toplumsal dışlanmadan vatandaşlık tartı̧̧malarına Suriyeli kent mültecileri. Akdeniz Üniversitesi İktisadi ve İdari Bilimler Fakültesi Dergisi, 18(37), 26-47.

Türkoğlu, O. (2011). Mülteciler ve Ulusal/Uluslararası Güvenlik. Uludağ Üniversitesi İktisadi ve İdari Bilimler Fakültesi Dergisi, 30 (2), 101-118.

Uzun, A. (2015). Günümüzün sosyal ve ekonomik sorunu olan Suriyelilerin mülteci ve ekonomi hukuku bakımından değerlendirilmesi. Ankara Barosu Dergisi 2015/ 1, 107-120.

Varyans Araştırma Danışmanlık Şirketi (Ocak-Şubat 2016). Türkiye’deki Suriyeli Göçmenlerin Toplumsal Kabul ve Uyumlarına İlişkin Rapor. Retrieved January 20, 2019 from the https://www.chp.org.tr/Public/0/Folder//65204.pdf).

Yaşar, R. (2014). Kilis’te Sığınmacı Algısı Toplumsal Otizm ve Ötekileştirmenin ilk Görünümleri, Kilis: Kilis 7 Aralık Üniversitesi Matbaası.

Yıldız, Ö. (2013). Türkiye Kamplarında Suriyeli Sığınmacılar: Sorunlar, Beklentiler, Türkiye ve Gelecek Algısı. Sosyoloji Araştırmaları Dergisi, 16 (1), 140-169.

Yılmaz, A. (2014). Uluslararası göç: çeşitleri, nedenleri ve etkileri. Turkish Studies International Periodical For The Languages, Literature and History of Turkish or Turkic 9 (2), 1685-1704. 